\title{
Exploration of EOP Turn and Its Path Oriented by Vocational Skills
}

\author{
Jiang Huan \\ College of Educational Science, Bohai University \\ Jinzhou, Liaoning Province 121003, China
}

\begin{abstract}
The training goal of higher vocational colleges is not only to cultivate students' knowledge and skills, but also to cultivate students' professional skills. According to the teaching needs of English skills for vocational skills in Higher Vocational colleges, this paper adopts the methods of literature analysis, questionnaire survey and case analysis, and takes the classes of five vocational post groups in my school as examples. By analyzing the development situation of Higher Vocational Colleges in China, this paper compares the different characteristics of EGP, ESP and EOP, and puts forward the idea of taking occupation as the basis. Skill-oriented EOP turning basis and path are of great help to improve the quality of teaching and help students' practice and employment.
\end{abstract}

Keywords-higher vocational colleges; vocational skills; eop turn; research on the basis and path

\section{INTRODUCTION}

With the development of global economy, China's opening to the outside world is becoming more and more vigorous, resulting in higher and higher requirements of employers for talent employees' foreign language proficiency. In order to better adapt to the development of society, vocational education in higher vocational colleges aims not only to cultivate students' knowledge and skills, but also to cultivate students' professional skills, mainly emphasizing professional skills, basic qualities and professional core competencies. Vocational skills refer to the skills and abilities that students need for future employment. Whether students have good vocational skills is the prerequisite for their successful employment. In accordance with the spirit of the Decision of the State Council on Vigorously Promoting the Reform and Development of Vocational Education "on Strengthening Vocational Guidance and Employment Services and Broadening the Channels of Graduates' Employment"[1], it is particularly important to mobilize students' enthusiasm for learning vocational skills and help them improve their vocational skills. Vocational skill education plays an increasingly significant role in improving the quality of workers, promoting employment, realizing the transformation of economic growth mode and delaying employment, alleviating employment pressure, promoting economic and social development, and promoting social harmony and stability. In the process of talent cultivation in Higher Vocational colleges, English education plays an important role in cultivating students' basic qualities. In order to improve the level of English teaching, it is imperative for English teaching in Higher Vocational Colleges to turn to EOP. It can not only effectively improve the quality of teaching, but also help students to better achieve employment and entrepreneurship.

\section{ANALYSIS OF THE DEVELOPMENT SITUATION OF HigHER VOCATIONAL EDUCATION IN CHINA}

In recent years, China's higher education has developed rapidly. Among them, the biggest change is that the number of higher vocational colleges has increased, and gradually formed its own school-running characteristics, training a large number of high-skilled application-oriented talents for national development and construction. We recall that since the 1990s, the state has issued many documents to encourage the development of Higher Vocational Colleges in terms of policies. From 1996, the classification of vocational school education was put forward, to 1998, the legal status of higher vocational education was further established, to 1999, it was further pointed out that higher vocational education and higher vocational education are an important part of higher education, and then to 2004, the development of Higher Vocational Education in China gradually shifted to pay more attention to quality improvement and content development. Exhibition, the development situation of higher vocational education is mainly reflected in strengthening curriculum construction and reform, enhancing students' professional ability, highlighting the training of practical ability, focusing on the "double teacher" structure of the teaching staff, and so on. With the strong support of the state, the development of Higher Vocational Education in China is in a good situation.

\section{Classification OF ENGlish TEACHING IN HigheR Vocational Colleges at THE PRESENT STAGE}

Hutchinson and Waters (1987) divided foreign language teaching into English for General Purposes (EGP) and ESP (English for Specific Purposes)[2]. At present, the academic circles divide ESP into three branches, namely EST, EBE and ESS. Each branch has two branches, namely EOP and EAP. Among these English teaching classifications, EGP, ESP and EOP are related to English teaching in Higher Vocational colleges.

\section{A. EGP refers to General English or Basic English.}

At present, most colleges and universities in China are conducting EGP English education from primary and secondary schools to universities, and then to postgraduate stage. These English courses generally start with five basic abilities of English learning, listening, speaking, reading, writing and translating. Through learning, students can basically apply the English language. Higher vocational colleges belong to the category of EGP before the implementation of English teaching reform. 


\section{B. ESP refers to English for specific purposes.}

Its characteristics are clear objectives, strong pertinence and high practical value. In order to meet the industry's demand for English, ESP came into being and developed rapidly. EGP takes grammar and vocabulary as its core, explores the rules of English language learning, and pays attention to the cultivation of basic abilities of listening, speaking, reading and writing. ESP emphasizes that learners should put learning objectives first and pay attention to professional needs. It is suitable for the study of professionals in all walks of life. It is more suitable for students in school to learn with their own professional knowledge, and to add weight to students' job hunting and employment.

\section{EOP refers to English for occupational purposes.}

EOP focuses on English that can be used in all kinds of occupational needs. It trains students to focus on vocational needs in the process of learning and take situational teaching as a method to closely integrate English language learning with students' graduation job-hunting and employment. Teachers create different simulated career scenarios according to students' different majors in the teaching process, so that students can experience the professional knowledge in their own situation, so that they can quickly adapt to the workplace environment after graduation and meet their needs for job hunting and employment.

\section{EXPLORATION OF EOP TURNING BASIS ORIENTED BY VOCATIONAL SKILLS}

Through the three forms and characteristics mentioned above, we can easily see that EOP, as a new teaching concept, is more suitable for higher vocational colleges as it is the same as vocational education. Therefore, it is of great practical significance to realize the EOP turn in English teaching in Higher Vocational colleges. EOP will become an inevitable trend in the development of English teaching in Higher Vocational colleges. After the research, the EOP turnaround guided by vocational skills is mainly based on the following basis:

\section{A. The exploration of vocational skills-oriented EOP turnaround relies on national documents at all levels.}

The EOP turning inquiry oriented by vocational skills mainly relies on the documents issued by the state at all levels. Firstly, the Opinions on Deepening the Reform of Higher Vocational Education with Employment Orientation promulgated by the Ministry of Education in 2004 (No. 1 of Education Higher Education) clearly put forward that the main school-running policy of higher vocational colleges is to take service as its purpose, employment as its orientation, take the development road of combining production with learning, and focus on training application-oriented high-skilled people. Only then. According to the guidance of this document, English teaching in higher vocational colleges must carry out the policy of "service as the purpose, employment as the orientation", strengthen the contact with enterprises, and explore new ways of school-enterprise integration and school-running. Secondly, the English Course Teaching Requirements for Higher Vocational Education formulated by the Higher Vocational College English Major Teaching Steering Committee of the Ministry of Education makes it clear that higher vocational English education should highlight vocational purposes and strive to explore the theory and methods of EOP teaching[3]. It is of great theoretical and practical significance to carry out the EOP turn research oriented by vocational skills, to explore new ways to improve vocational skills under the new situation and to cultivate students' vocational English competence for future jobs.

\section{B. The exploration of vocational skills-oriented EOP turnaround relies on vigorous development.}

In recent years, vocational education has become an important part of higher education in China[4]. With the rapid development of higher vocational colleges, a large number of applied skilled personnel have been trained for the country. After graduation, they became front-line workers in various enterprises and factories. The goal of vocational education is not only to cultivate students' knowledge and skills, but also to cultivate their craftsmanship and innovation and entrepreneurship. While learning basic theories and knowledge, it emphasizes professional skills, basic qualities and core professional competence, which has a strong pertinence. Under the background of today's vigorous development of vocational education, it is imperative for EOP turnaround which is oriented by vocational skills, and it will certainly contribute to the training of vocational education talents and play a positive role in promoting them.

\section{The exploration of vocational skills-oriented EOP turnaround relies on the reform intensity of improving students' communicative ability of English in higher vocational colleges}

In view of the contradiction between English practical teaching and social needs in vocational colleges, the reform of English teaching is imperative, which mainly reflects in changing the relatively weak situation of English practical teaching. In order to solve this problem, we must persist in creating a diversified English practice teaching mode. All of these provide a reliable guarantee for EOP turning inquiry oriented by vocational skills.

\section{The exploration of vocational skills-oriented EOP turnaround relies on the competitiveness of vocational college students in the workplace}

With the continuous popularization and universalization of education in China, the number of college students has increased year by year, and students in vocational colleges are no exception. However, the employers have a high demand for students, which brings great pressure to students' employment. At present, vocational colleges have been committed to improving the comprehensive competitiveness of vocational students. In order to improve students' professional skills, we should also cultivate students' professional qualities and general abilities to enhance students' competitiveness in the workplace.

\section{EXPLORATION OF EOP TURNING PATH ORIENTED BY VOCATIONAL SKILLS}

EOP teaching reform in vocational education conforms to the cognitive pattern of English language and the development trend of vocational colleges in China at present. It combines English language learning with communication in the workplace, which embodies the practicability and professionalism of English teaching. It is in line with the development direction of 
vocational education to take vocational skills as the orientation and to cultivate students' practical ability of using language as the starting point.

The author takes the students of five vocational post groups (tourism and hotel post group, marketing post group, e- commerce post group, construction project post group and automobile marketing post group) of Liaoning Polytechnic Vocational College, a vocational college in Liaoning Province, as the subjects of investigation. And a series of investigations has been carried out according to the English teaching situation of graduates and the actual needs of English in the workplace.

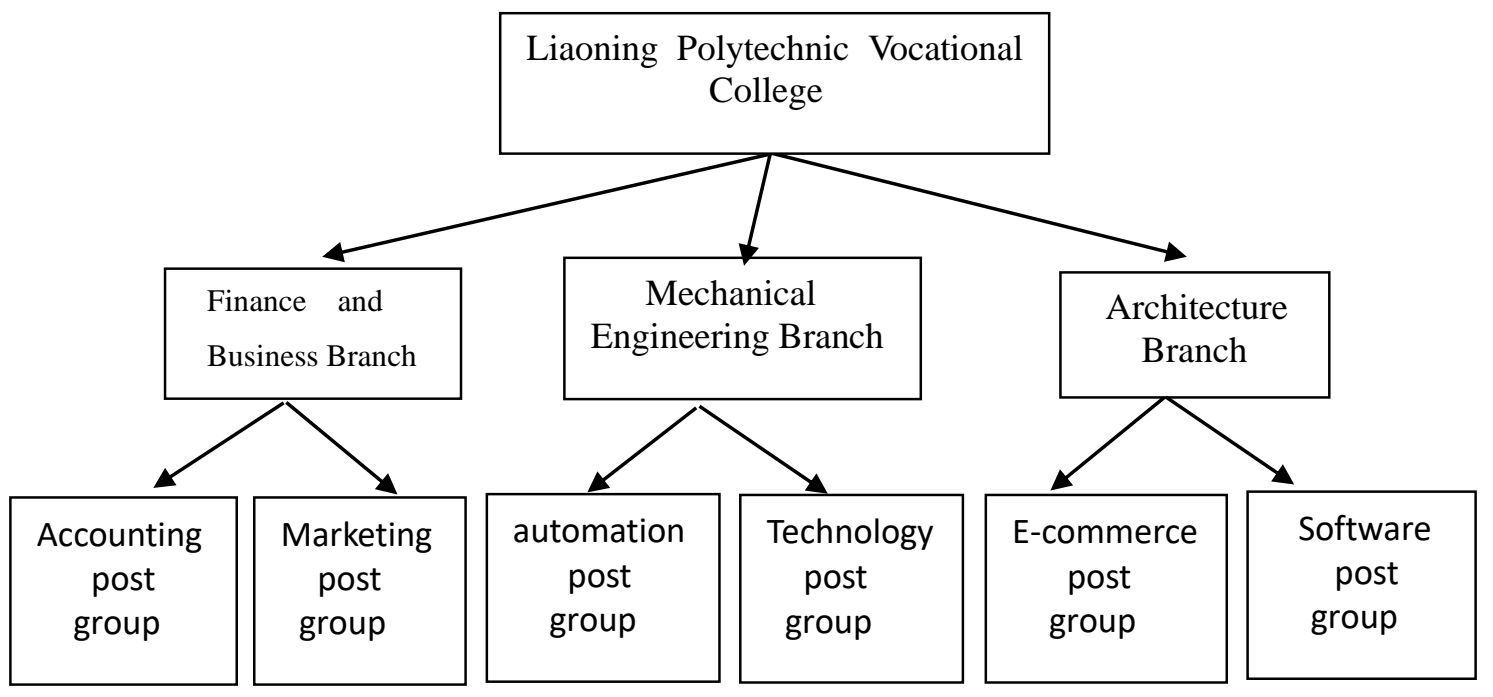

Fig. 1 Post Groups of Liaoning Polytechnic Vocational College

Based on the statistical analysis of the survey, the following conclusions are drawn: firstly, it is necessary to implement EOP vocational English teaching in these five job groups; secondly, it is necessary to make a comparative analysis of the data after the enterprise managers fill in questionnaires, among which tourism and hotel job groups and marketing job groups have a higher and more specific demand for vocational English. They hope students can pass the English level examination, have a solid foundation in language and application ability, and have more opportunities to apply English in specific jobs. Thirdly, among the graduates of Grade 16 and the interns of Grade 17, we can find out through the questionnaire that students are more aware of their needs once they start working. They believe that vocational English can enhance their competitiveness of the workplace. If they can use English skillfully in their work, they will have more opportunities for training and promotion in the future, as well as a better development space.

After the implementation of the specific survey, based on the results of the survey, this paper puts forward the following analysis of vocational skills-oriented EOP turning paths.

\section{A. Reconstructing the English Course Teaching System of Vocational Education}

The <Requirements for English Course Teaching in Higher Vocational Education> has mentioned the nature and teaching objectives of English Course in higher vocational education. It points out that English course in higher vocational education is a compulsory public basic course for students of higher vocational education. It serves the goal of cultivating high-end skilled talents for production, construction, service and management. It is also an important course to cultivate students' comprehensive quality and enhance their ability of sustainable career development [5].

According to the requirements above, it is urgent to reconstruct the English teaching system of vocational education. The author believes that the reconstruction of English course teaching system in vocational education can be based on the following aspects:

Firstly, we should redesign the talent training program. The author takes Liaoning Polytechnic Vocational College's Professional Talents Training Program (2019 edition) as an example to illustrate how to reconstruct the curriculum system of vocational education. In Liaoning Polytechnic Vocational College's Professional Talents Training Program of 2019 edition, the traditional college English teaching system has been broken. The English course has been named as Public English, and together with other public basic courses, it forms a public compulsory course. The courses are offered in the first and second semesters, with a total of 4 credits and 64 courses per semester, 2 hours per week. Among them, the first semester is the examination course, and the second semester is the evaluation course. 
TABle I Teaching Plan of Liaoning Polytechnic Vocational College's Professional Talents Training Program 2019

\begin{tabular}{|c|c|c|c|c|c|c|c|c|c|c|}
\hline \multirow{3}{*}{$\begin{array}{l}\text { Course } \\
\text { Structure }\end{array}$} & \multirow{3}{*}{ Name } & \multirow{3}{*}{ Course nature } & \multirow{3}{*}{ Course Name } & \multirow{3}{*}{$\begin{array}{l}\text { Examination } \\
\text { methods }\end{array}$} & \multirow{3}{*}{ Credit } & \multirow{3}{*}{ Theoretical hours } & \multicolumn{4}{|c|}{ Term Schools Allocation } \\
\hline & & & & & & & \multicolumn{2}{|c|}{$\begin{array}{l}\text { First } \\
\text { school year }\end{array}$} & \multicolumn{2}{|c|}{$\begin{array}{l}\text { Second school } \\
\text { year }\end{array}$} \\
\hline & & & & & & & 1 & 2 & 1 & 2 \\
\hline \multirow{10}{*}{$\begin{array}{l}\text { Public } \\
\text { Course }\end{array}$} & \multirow{10}{*}{ Basic } & \multirow{10}{*}{ Obligatory } & Socialist theory & test & 4 & 56 & & 4 & & \\
\hline & & & Morality and LOW & test & 3 & 48 & 3 & & & \\
\hline & & & Moral educationFature & check & 1 & 16 & 1 & & & \\
\hline & & & Sports & check & 3 & 8 & 2 & 2 & 1 & 1 \\
\hline & & & Psychology & check & 2 & 22 & & 2 & & \\
\hline & & & employment guidance & check & 2 & 22 & 1 & & & \\
\hline & & & Form Policy & check & 1 & 32 & 1 & & & \\
\hline & & & Computer Foundation & test & 3 & 24 & 3 & & & \\
\hline & & & Traditional culture & test & 2 & 32 & & 2 & & \\
\hline & & & General English & Test & 2 & 32 & 1 & 1 & & \\
\hline
\end{tabular}

Second, reconstruct the teaching system of English course in vocational education. To set up Public English 1 and Public English 2 in Liaoning Polytechnic Vocational College Professional Talents Training Program (2019 edition). The specific courses are as follows: In the first semester, General English should be offered in all majors for 32 hours and 2 credits. The main content of the course is language culture knowledge and language skills training, which enriches the English curriculum and meets the learning needs of students of different majors; the second semester is Vocational English, which is EOP teaching, should be offered in all majors, with a total study time of 32 hours, and 2 credits. EOP teaching is different from EGP in that it develops and constructs the teaching content system with professional needs as the main line, highlighting professional characteristics. The content system no longer emphasizes the balanced development of listening, speaking, reading, writing and translation, and repeats the basic language structure and vocabulary arrangement of junior and senior high schools, but is related to students 'personal needs, future career and industry needs. It can design several teaching modules, for example, entry-level job (mainly related to job resume production, interview skills, etc.), career fighting (company or job introduction, product introduction, work-flow introduction, etc.), career life (company training, promotion skills, career design, etc.). All of these curriculum content designs are based on the typical work tasks and work process direction. Simulating the future of students' workplace vividly can effectively enhance the competitiveness of students' internship and employment. The determination and design of EOP content system requires the participation of senior professionals in industry or enterprise and English teachers or professional teachers who undertake relevant courses in vocational colleges to ensure the science and practicability of EOP content system[3].

\section{B. Developing EOP course textbooks.}

At present, the textbooks used in public English courses in higher vocational colleges are mainly the following two types:

Firstly, the national planning textbooks for higher vocational colleges (for non-English majors). This is the textbook that most higher vocational colleges are choosing to use. These textbooks are in line with the English level of higher vocational students, and their contents are rich and abundant. However, the contents of these textbooks are mostly about general English. Some of them are designed for the English practical ability test, which has certain practicability. However, the shortcomings are that the depth and breadth of the field of Vocational English are not enough, there is no obvious workplace characteristics, and the textbooks need to be improved in terms of practicability and applicability, which can not meet the students' needs of different majors [6].

Secondly, school-based textbooks are independently developed according to the characteristics of different higher vocational colleges. This kind of textbook can be compiled according to the characteristics of different majors, and can be completed by professional teachers working together. It is more professional and has better guidance for students' job hunting and employment.

According to the investigation of the usage of the above two kinds of textbooks, it is necessary to develop EOP curriculum textbooks. The development of EOP curriculum textbooks depends on the joint development of front-line English teachers, industry enterprises and curriculum development experts. After the investigation and study of different job groups, the demand for English competence in different positions is analyzed, and then the corresponding knowledge and competence requirements are refined and organized. Different higher vocational colleges can compile textbooks according to their own conditions by combining foreign advanced EOP textbooks with the actual situation of their own teaching, highlighting the practicability and applicability of the textbooks.

\section{Reform the traditional teaching methods and evaluation methods}

The traditional English classroom teaching mode is guided by teachers' teaching and students' participation in classroom teaching. After the reform, the traditional mode of English teaching is broken. The following teaching methods are mainly adopted:

Firstly, adopt the student-centered teaching mode with "training" as the main focus. Teachers play a leading role in guiding students and organizing them to strengthen their training. They only teach one-third of the time in class. The remaining 
two-thirds of the time is reserved for students to strengthen their training, discuss freely and simulate situational performances. This reform of teaching method based on "training" will greatly enhance students' interest in learning, and basically ensure that every student will actively participate in every topic.

Secondly, the "task-driven method" will be used throughout the classroom training, so that each group and each student can participate in tasks. Students receive tasks in groups. The scope of the task is very wide. Generally speaking, students are set up according to the scenarios practised in this unit. They can only accomplish the team work well by taking part in group discussions after class and bringing team work spirit.

Thirdly, we should guide students to truly experience happy English by "situational interaction method", promote the formation and development of students' language ability, and show the results of group students by recording micro-lesson videos. In situational performances, students are encouraged to use a combination of multimedia, like words, images, sounds and videos to record micro-lesson videos so as to enrich the teaching content and create a real language environment.

Fourthly, in the process of examination, we should not consider the final exam's grade as the student's term grade. It is better to adopt the three-stage examination method, which integrates the students' ordinary performance grade, the midterm exam grade and the final exam grade to give marks, so as to greatly increase the accumulation of students' daily participation in classroom activities, as well as to receive good reform results.

\section{Strengthen EOP Teachers' Team Construction}

EOP teaching has a bright demand for higher vocational colleges to strengthen the construction of teaching staff. This requires that teachers who offer EOP courses not only have solid English language knowledge and skills, but also have certain EOP theory and relevant professional background knowledge. Higher vocational colleges should strengthen the construction of teaching staff from the following aspects to improve the level of teaching staff:

Firstly, strengthen the construction of "double-qualified and dual-competent" teachers team. In recent years, higher vocational colleges have gradually begun to carry out the work of qualifications identification of "double-qualified and dualcompetent" teachers. Most of the public English teachers in higher vocational colleges graduate from English majors. Their educational background is not directly related to engineering and science. It is very difficult for them to develop into "doublequalified and dual-competent" teachers by their own abilities. The effective way is to implement the double certificate system, which combines the teachers' qualification certificate and the professional qualification certificate in colleges and universities, so that they can gradually reach the level of "double-qualified and dual-competent" teachers.

Secondly, encourage English teachers to participate in professional construction and students' in-school training courses, to participate in professional related scientific research, to participate in the work of master studios and professional student associations, to gradually accumulate their own professional knowledge, and then to combine with their own basic knowledge of English, in order to better accomplish the shift of teachers to EOP. We can try to divide the English teachers into several groups, each focusing on a professional direction, so that English teachers can understand the theoretical knowledge and practical skills of the major as soon as possible, and turn to EOP teachers more quickly.

Thirdly, expand and upgrade in service training of EOP teacher team. Higher vocational colleges should provide teachers with a variety of ways of professional knowledge training, encourage teachers to actively participate in student internship guidance, visit internship units, and accumulate practical experience. In addition, higher vocational colleges should strengthen the cooperation between colleges and enterprises, take the method of inviting in and out, and employ experts from enterprises to guide specific teaching work, so as to effectively promote the improvement of English teaching quality in Higher Vocational colleges.

\section{CONCLUSION}

To sum up, the teaching reform of vocational skill-oriented EOP turning conforms to the cognitive pattern of English language, as well as the development trend of vocational colleges in China at present. And the combination of English language learning and workplace communication reflects the practicability and professionalism of English teaching. It is in line with the development direction of vocational education to take vocational skills as the orientation and to cultivate students' practical ability of using language as the starting point. In theory, the framework of EOP education system has been further enriched and perfected. In practice, it can provide specific guidance for the teaching mode, content and methods of English education in vocational colleges. If EOP reform turns to success, we will continue to track the five occupational groups involved in the investigation and study, compare the different effects before and after the implementation, sum up experience, and strive to promote the use of various professions as soon as possible, so as to make the research of this topic more valuable.

\section{REFERENCES}

[1] Decision of the State Council and the State Council on Vigorously Promoting the Reform and Development of Vocational Education [J]. Shandong Human Resources and Social Security, 2002 (11): 4-7.

[2] Ni Yuhong. EOP Turn and Its Influencing Factors in English Teaching in Higher Vocational Colleges[J]. Foreign Language World. 2013( 8): 9096.

[3] Liu Xiaoyi. EOP Turn and Path Construction of English Teaching in Higher Vocational Colleges[J]. Journal of Chengdu Normal University, 2015,31(2):50-53.

[4] Li tao, Xuping. Talking about How to Adapt the Teaching of Mechanical Drawing in Higher Vocational Colleges to the Requirements of Professional Training Objectives. Science and Technology of West China. 2011(7):2.

[5] Wu Yuguang. Design and Practice of Micro-Course Teaching in Public English Course of Higher Vocational Education from the Perspective of MOOC. Journal of Hunan University of Science and Engineering. 2018(12):123-125.

[6] Zhao Hong. On the Turning of Public English Teaching to EOP in Higher Vocational Colleges. New Curriculum Research. 2015(1):67-69. 